\title{
School textbook as an object of pedagogical research
}

\author{
Yaroslava Kodliuk ${ }^{1, *}$, Nadiya Bibik ${ }^{2, * *}$, Ihor Kodliuk ${ }^{3, * *}$, Liubov Kodliuk ${ }^{4}$, and Olha Radchenko $^{1, * * * *}$ \\ ${ }^{1}$ Ternopil Volodymyr Hnatiuk National Pedagogical University, 2 M. Kryvonosa Str., Ternopil, 46027, Ukraine \\ ${ }^{2}$ Institute of Pedagogy of the National Academy of Educational Sciences of Ukraine, 52-D Sichovykl Striltsiv Str., Kyiv, 04053, Ukraine \\ ${ }^{3}$ Technical College of Ternopil Ivan Puluj National Technical University, 13 L. Kurbasa Str., Ternopil, 46016, Ukraine \\ ${ }^{4}$ Ternopil College of Food Technologies and Trade, 73 Stepana Bandery Ave., Ternopil, 46011, Ukraine
}

\begin{abstract}
The article deals with investigations of scientists in the field of school textbook theory. The material has been structured taking into account the main components of this field of knowledge: purpose (the dual essence of this type of educational literature has been revealed - it is a carrier of educational content and teaching aids; position of the textbook as a model of integral learning process has been substantiated (systematization, consolidation and control, self-education, integrating, coordinating, developmental-educational), structure (general didactic structure of the school textbook covers the text and non-text components - the apparatus of mastering, illustrative material, orientation apparatus), methods of analysis and evaluation (distinguish traditional and theoretical) - analytical and formalized methods; the structural-functional approach to the textbook analysis has been proved). The peculiarities of textbooks for elementary school have been analyzed: the most complete definition of this phenomenon has been formulated; the leading functions of the textbook addressed to junior students have been defined - informational, developmental, educational, motivational; the features of structural components (taking into account the age of students) have been specified; methods of analysis and evaluation of the textbook have been classified: methods of analysis of the manuscript, methods of evaluation of the textbook itself, diagnostic evaluation ex post facto; a comprehensive approach to the analysis of textbooks for elementary school has been proposed; methods of analysis of certain aspects of the textbook (motivational component, developmental orientation, etc.) have been offered.
\end{abstract}

\section{Introduction}

The information society determines the requirements for general education of students as a necessary component of the quality of the national education system - to obtain the ability to learn, to gain the ability to self-study throughout life. In this aspect there is a need for modernization forms, methods and learning tools, but the dominant role in this process belongs to the content of education as a model of society's requirements for younger generation. A textbook is a material expression of the content of education, so this type of educational literature must meet the characteristics of the dominant concept - a personality-oriented one - of teaching at a particular stage of development of pedagogy and school.

Let's admit that school textbooks have been the subject of researches by a number of scientists in different directions: essence, functions and structure of a textbook (V. Beilinson [1], V. Bespalko [2], D. Zuev [3], E. Perovsky [4]) ; analysis and evaluation of a textbook (V. Beilinson [1], F.-M. Gerard [5], Y. Kodliuk [6], X. Roegiers [7], O. Topuzov [8]); features of a textbooks for elementary school (N. Bibik [9], L. Zankov [10],

\footnotetext{
*e-mail: yp.kodliuk@gmail.com

**e-mail: binam8@ukr.net

***e-mail: ihor.kodliuk@gmail.com

****e-mail: yan.olga1208@gmail.com
}

Y. Kodliuk [6], O. Savchenko [11], N. Khrebtova [12]); methodical bases of creation textbooks on separate subjects (N. Burynska [13], V. Redko [14], I. Smagin [15]). UNESCO researches in the field of school textbooks is an important area of this investigation: ways to reflect in the school textbook the concept of learning for sustainable development (J. Gilbert [16], P. Lengrand [17]); educational, developmental and upbringing potential of the textbook (E. Gachukia [18], D. Georgescu [19]); approaches to the analysis and evaluation of this type of educational literature (A. Reints [20], R. Seguin [21]). The process of formation of the ability to work with textbooks indirectly deepen theoretical aspects of textbooks, which relate to the organization of work with textbooks (Z. Berkyta [22], O. Yanchenko [23]). Thus, currently there is no special study that would comprehensively represent the approaches of scientists to the construction of a school textbook as a model of a holistic learning process in a personcentered paradigm of education.

The purpose of the article is to systematize researches of scientists in the field of school textbook theory as a conceptual basis for creating a textbook. With this aim: to clarify structural components of the theory of school textbooks; to analyze available scientific fund on the problem of school textbook science; to single out researches of scientists in the field of school textbook theory for each of its 
structural components; outline new trends in this area of pedagogical research.

\section{Results}

Let's admit that theoretical foundations of textbooks have been explored as a special branch of scientific knowledge combining pedagogy (especially didactics), subject methods, psychology - the theory of school textbooks (or textbook). A textbook models an integral teaching process (content, forms, methods, etc.), it is primarily the object of pedagogical researches, including didactic.

There are two levels in the theory of a school textbook - general theoretical and methodical (D. Zuev [3], I. Lerner [24], etc.). At general theoretical level universal principles of designing a textbook (functions, structure, etc.) has become the subject of study; methodical level is expressed in the application of general provisions to a textbook creation on individual subjects.

\subsection{General theory of the textbooks}

Let's reveal the main experience of researchers in the general theory of the school textbook. The main structural components of this field of knowledge are as follows: the essence of the textbook, its functionality, the structure of the textbook, types of textbooks, methods of analysis and evaluation of the textbook, and others (figure 1).

Textbooks have become the subject of theoretical analysis since 1955, when the results of scientific investigation of E. Perovsky "Methodical construction and language of the textbook for secondary school" were published [4]. The author provided the definition of this phenomenon: "This is a textbook that contains a systematic presentation of knowledge in a particular subject, necessary for students to learn" [4, p. 22]; its structural components were singled out. Let's admit that the scientist did not use the term "structure", but "methodical construction of a textbook", which meant the internal form of the structure of the textbook, according to him. E. Perovsky attempted to identify original elements of the textbook: introduction, sections, articles (paragraphs), drawings, conclusions, questions and tasks, additional apparatus (various indexes, reference tables, etc.). The lack of a feature based on which the specified division was offered was a significant disadvantage of the proposed structure [3].

The theory of the school textbook gained the highest development in the researches of V. Beilinson [1], V. Bespalko [2], D. Zuev [3], and I. Lerner [25, 26]. Here's the list of their investigations aspects of school textbooks: purpose of the textbook, its functions, structure, methods of analysis and evaluation of the textbook.

Scientists admit its dual essence - the content of education and teaching tools, as the unity of content and procedural aspects. Significantly specifies the studied aspect of the problem of I. Lerner's position on the textbook as a strategic and tactical (methodological) model of the learning process [26]. As a strategic model, it reflects the main elements of this process: goals, content, techniques and methods, organizational forms. At the same time, according to the scientist, each textbook is a tactical model of the educational process, as it offers its universal structure. The teacher modifies the proposed model, transfers its main features to the real learning process, taking into account the age and individual characteristics of students, the type of school, the conditions in which it occurs.

The analyzed materials showed that scientists mostly admit the following functions: informational, transformational, systematization, consolidation and control, selfeducation, integrating, coordinating, developmental and educational; the concept of the leading function has been proposed (developmental and educational function [3], the function of leading the process of obtaining the content of education [25]).

The general didactic structure of the textbook was developed by D. Zuev. It covers the following elements: the text - the main, additional, explanatory, and non-textual components - the apparatus of the organization of assimilation (educational tasks and exercises, samples of records, memos, summary tables, printing selections, etc.), illustrative material (leading illustrations, equal to the text and those that serve the text), the apparatus of orientation (preface, table of contents, rubrication, signals-symbols, list of references, indexes (subject, noun, subject-noun, etc.), footer), selected taking into account the leading function.

V. Beilinson proposed a generalized classification of methods of analysis and evaluation of school textbooks. The scientist divided the available methods into two groups: traditional, including peer-review, comparative review, historical-comparative analysis, study of the opinion of those who use textbooks (open questionnaire, interview, general survey) and theoretical-analytical and formalized (scientific and professional accuracy of the textbook, checking the compliance of textbooks to the curriculum, scoring methods, system-structural, partially-aspect, narrow-functional, statistical). A special role in the context of this the well-known didactic assigns partiallyaspect and narrow-functional methods, as they are "developed to identify and improve certain properties of a textbook or a training kit" [1, p. 272]. The structuralfunctional approach to the analysis of this type of educational literature was substantiated, the structural components of which were structural analysis of the textbook and its functional characteristics.

Let's admit that at present the theory of school textbooks has been developed mainly at methodological level, as proved by the analysis of articles in the collection of scientific researches "Problems of modern textbooks", which has been periodically published by the Institute of Pedagogy of NAPS of Ukraine since 1999 (for example, $[9,27,28])$.

The researches of UNESCO scientists significantly deepen the understanding of the purpose of the textbook and its place and role in the educational process. A lot of statements relate to teaching for sustainable development, in particular, much attention is paid to the role of the textbook in achieving the goals of sustainable development: advice to compilers on how to integrate competencies to 


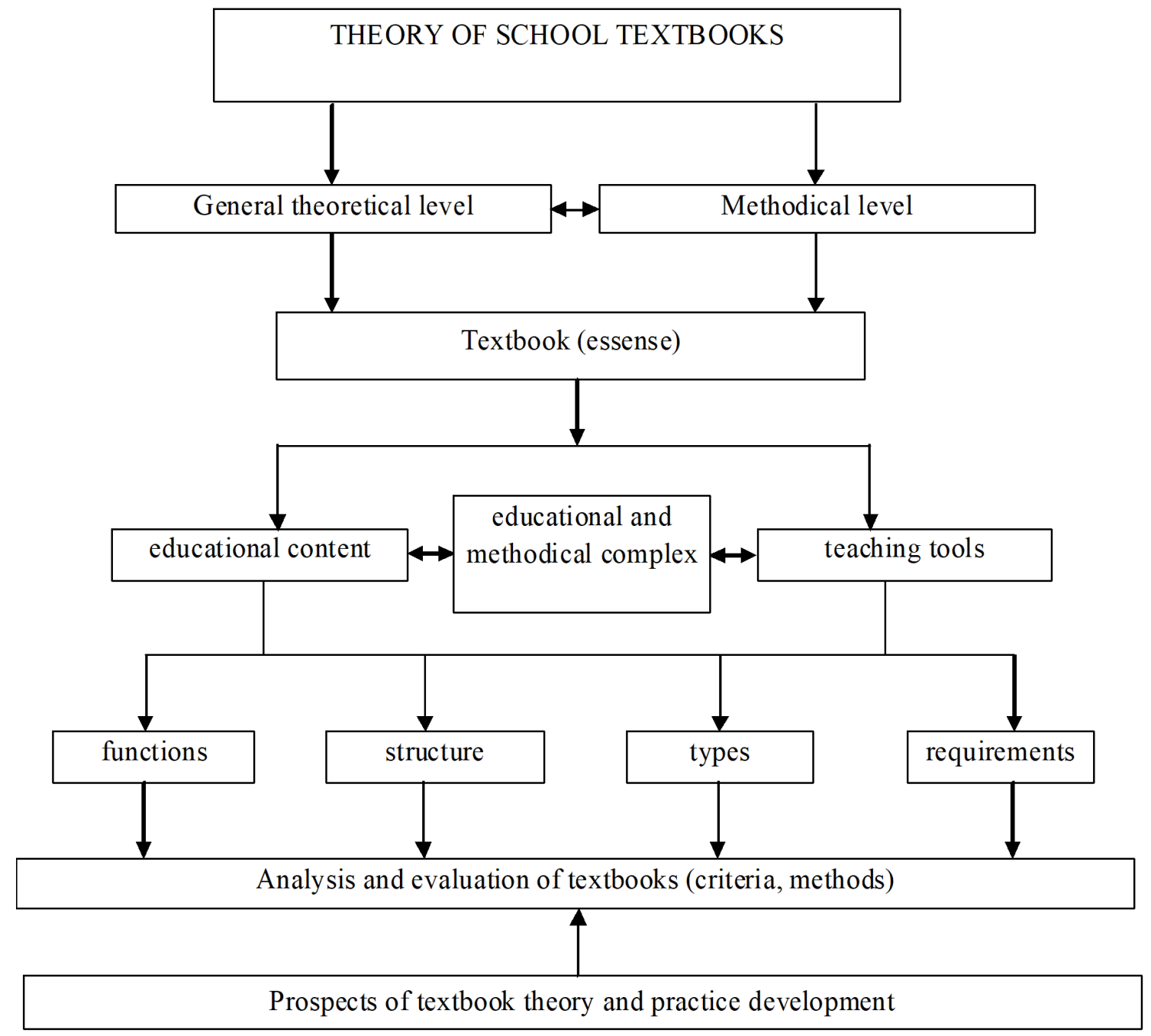

Figure 1. Structural components of theory of school textbook

ensure sustainable development in the subject content; criteria for selecting topics for sustainable development training; educational tasks that contribute to the achievement of sustainable development goals [16, 17].

The educational, developmental and upbringing potential of school textbooks has been revealed. It has been found that the educational potential of the textbook is that the book is considered a reliable source of information. The content of the textbook should be based on modern scientific achievements and meet the requirements of pedagogical practice. Developmental potential includes a motivational component and motivating students to further search. UNESCO scientists also point to the role of the textbook as a means to achieve the goals of sustainable development. The educational potential of the textbook is realized through the proper reflection of cultural values, forming the concept of culture of their own people and intercultural consciousness. This also includes the problem of gender equality, peace and its implementation in everyday situations, overcoming stereotypes and prejudice against people [18, 19].

UNESCO researches on the analysis and evaluation of school textbooks covers two aspects - the development of criteria for evaluating the quality of the book and appropriate methods of collecting information about it [20,21]. Let's admit the research of A. Reints, who substantiated 18 criteria for evaluating the quality of textbooks and other educational materials. Note that the following aspects of the book are subject to analysis: content (compliance with the curriculum, correctness and relevance of the information provided, etc.); pedagogy (conformity of the didactic model to modern psychological requirements; possibilities of using interactive, group and active learning, etc.); embodiment (readability, effective and appropriate illustrations, etc.) [20].

\subsection{Features of textbooks for elementary school creation}

A separate area of the researches concern the peculiarities of the construction of the textbook for elementary school (N. Bibik [9], L. Zankov [10], Y. Kodliuk [6], O. Savchenko [11], N. Khrebtova [12] and others).

Researchers have proposed the most complete definition of this phenomenon: "it is a type of educational literature that represents knowledge and activities in a particular 
subject in accordance with state educational standards and curriculum requirements, taking into account the features of this subject (its dominant function), type of school, age and other features of students and it is based on the dominant concept of teaching" [6, p. 19]. Let's analyze this aspect of the problem.

The statement on a textbook for elementary school as a model of the learning process, which is reflected in the content of a textbook (a textbook is the main source of the content of elementary education) and in didactic organization of educational material (as a means of learning), has been specified. The textbook is created to capture its main elements as a source of educational content: knowledge, skills, creative experience, emotional and value attitude to the world. At the same time, the is considered by the scientists as a means of learning (for teachers and students), and it is appropriate to reflect the methodological approaches to the study of the material, the form of organization of educational activities of students; to form the ability of junior students to work with educational literature by means of the textbook.

The approach of scientists to the selection of the leading functions of textbooks for elementary school is noteworthy, such as: developmental (L. Zankov [10]); informational, developmental, motivational (O. Savchenko $[11,29]$ ); motivational (N. Bibik [9], N. Khrebtova [12]) and others.

The leading functions of a modern textbook, addressed to junior students, are information, development, education, motivation (Y. Kodliuk [6, 27, 28]), based on the following considerations: firstly, textbooks for elementary school should model the integral pedagogical process, including learning activities as a leading one at this age, i.e. fully implement motivational, informational and developmental functions that reflect the structural components of this activity; secondly, the philosophy of childcenteredness focuses on the proper presentation in the textbook of the experience of emotional and value attitude to the world as an element of educational content, ie provides strengthening the educational orientation of the textbook (taking into account the sensitivity of junior students to educational influences). Information function is realized by presenting knowledge of a particular subject and activities aimed at obtaining them. The developmental function of a textbook is to provide the means of a textbook developmental impact on the personality of the junior student, which is carried out in the following areas: development of mental processes; formation of general educational skills and abilities; development of creative abilities. The main purpose of educational function is to reflect experience of emotional and value attitude to reality in textbooks properly (taking into account the specifics of the subject). Motivational function directs the development of students' intellectual feelings, positive studying motives, cognitive needs and interests, i.e. the affective sphere of students [6].

Regarding the structure of the textbook, a text traditionally plays dominant role - it's a complex system that includes both its external design, which helps to differentiate importance of educational material, and internal struc- ture (pedagogically appropriate content, successful speech design, logic and consistency of presentation), which ultimately ensure the implementation of the basic functions of studying - educational and developmental. We consider the classification of educational texts by functional style to be scientifically productive. Taking into consideration the main function of a text as a structural component of textbooks is to share knowledge, and the main types of knowledge are knowledge about the world around us, about ways of cognitive and practical activities and values, subjectoriented, instrumentally oriented and value-oriented texts are distinguished.

Features of the textbook addressed to junior students are largely due to the specifics of the use of educational tasks and exercises - the main element of the apparatus of the organization of assimilation, which must meet the following requirements: be based on the content, motivation and procedural components of studying; to determine the development of not only reproductive, but also creative activity and reflexive qualities of a student; be located in the textbook in accordance with the main stages of the studying process; fully represent the four-component concept of the content of education (knowledge, skills and abilities, creativity, emotional and value attitude).

Illustrative material is closely connected with the subject content of the textbook, which contains certain information, as well as a means of educational influence on students. The didactic bases of the textbook illustration for elementary school have been proposed: full realization of the leading functions of the textbook - informational, developmental, educational and motivational; connection of illustrative material with other structural components (first of all with the text) has been didactically proved; adequacy of visual images to age features of junior students [6].

Analysis of textbooks for elementary school shows that there is an intensive use in the structure of school textbook of various elements of the apparatus of orientation at the present stage, especially signals-symbols, but the problem of their unification remains relevant (at least within one educational field).

Clarification of theoretical foundations of the textbook made it possible to create a model of the modern textbook for schools of the first degree (figure 2).

The variable system of school education determines the development and creation of variable educational literature. We distinguish between variable and alternative textbooks: variable are different types of textbooks that are carriers of the content of education at a certain level of education (for example, within the school of the first degree); alternatives are textbooks of the same type that offer different learning technologies, author's approaches to the didactic and methodological organization of educational material. Given this we offer the classification of textbooks by the content of education: by the depth of reflection of the content of education (basic, including parallel, and differentiated); by the nature of the reflection of the content of education (integrated and textbooks for certain educational areas); by the method of organizing educational material (problem, discussion, programmable, developmental). 


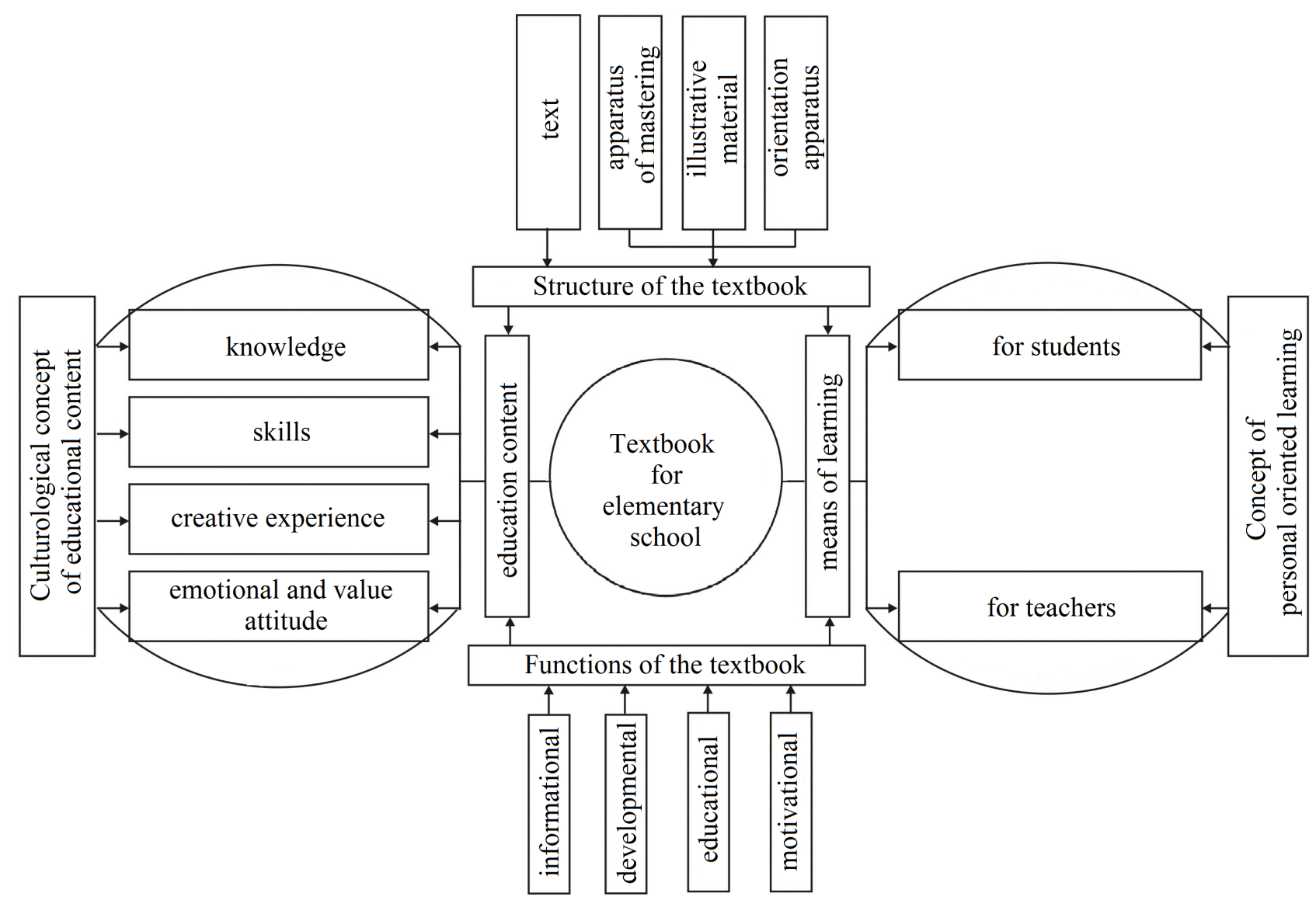

Figure 2. Theoretical model of the modern textbook for elementary school

There are special methods of researching a textbook and collecting information about it. Due to the fact that the textbook can be analyzed at different stages of its development and creation, the following classification is considered expedient and easy to use: methods of manuscript analysis (descriptive, comparative, matrix); methods of assessment of the actual textbook (observation, questionnaire of teachers, survey of students, study of the level of knowledge of students, peer review); post factum diagnostic assessment as an intermediate form of the textbook verification.

In order to find out the most important generalizing characteristics of the textbook, it is offered to use a comprehensive analysis of the textbook addressed to junior students in the following areas: functions (informational, developmental, educational, motivational); structure (text, apparatus of organization of assimilation, illustrative material, apparatus of orientation); printing design (compliance with sanitary and hygienic requirements, aesthetics of the textbook); the textbook in the system of educational and methodical complex (the textbook is an independent element of the educational process; connection of the textbook with other components of educational complex and consistency; textbooks and methodical literature for teachers, their connection) (taking into account the developed criteria).

The scientists attempts to offer methods of analysis of certain aspects of the textbook (scientific, educational ori- entation, etc.) are pedagogically proved. Here are some samples of the following methods developed by members of the school textbook research laboratory of Ternopil Volodymyr Hnatiuk National Pedagogical University:

- motivational component of the textbook for elementary school. Motivational component of the textbook is realized through the motivational function and covers the following components: emotional content of the educational material; ways of its didactic organization; the textbook design. According to the selected components, a method of analysis of this component are developed, which provides a research of textbooks according to the following criteria: selection of information taking into account cognitive interests of students (use of interesting cognitive material, genre diversity, coverage of personally relevant topics), provision of appropriate features of the content of educational material (emotionality curiosity, accessibility, value) - emotionality of the content of educational material; availability of practical works, didactic games, means for emotional and evaluative activity, group forms of work, certain ways of teaching, developmental means, means of goal setting - ways of its didactic organization; compliance with hygienic, aesthetic and didactic criteria - the textbook design [12];

- developmental function of the textbook. It is proved that the developmental influence of the textbook on a personality of a junior student is carried out in the following di- 
rections: development of mental processes, formation of general habits, skills and abilities. For the purpose of the analysis of the function, there are different types of educational texts of educational direction (instrumentally oriented) in textbooks for students of elementary school (texts on development of mental processes, on formation of general skills and abilities, on formation of creative abilities) and relevant tasks and exercises, taking into account semantic, motivational and procedural aspects of learning. A quantitative and qualitative description of educational tasks should be the next step, which makes it possible to determine the following points [6]:

a) whether all components of the developmental function are implemented in the textbook;

b) what is the percentage of these exercises (by groups) of the total number of educational tasks;

c) what types of tasks and exercises play the most and the least important role in the textbook;

d) an adequacy of quantitative and qualitative characteristics of educational tasks of one textbook with similar indicators of another one (within one class - for different subjects, compared with textbooks (one subject) for different forms - both previous and next - in order to clarify positive dynamics of inclusion of these elements of the apparatus of the organization of assimilation in the content of textbooks);

- technological structure of the textbook addressed to junior students.

More and more scientists think that the distinctive feature of the modern textbook is its adaptability, although the achievements of researchers in this aspect are not full. O. Savchenko associates this sign of the textbook with two important points [29]:

1) the modern textbook should have clear signs of a teaching technology, the teacher could see the future scenario of learning activities of students viewing its contents;

2) it has gradually but consistently and persistently prepare children for learning. According to the pedagogue, this aspect must be appeared in several areas, especially in the motivational (use variety of means to encourage and support the success of self-employment in the content of a textbook, the development of cognitive needs and interests) and procedural (the author's ability to design self-educational process in the text, tasks, schemes etc.).

Our understanding of technological textbook for elementary school based on its interpretation as a mean of training for teachers (to offer a tentative model of organization in school) and for students (to ensure mastery of knowledge and skills, to form the ability to learn). This technological structure of the textbook is directed to junior students. It is such a feature, due to which an educational book effectively serves as a means of training for teachers and students, and it is integrally simulates educational process; it grands technological norms and reflects some teaching technologies based on the dominant paradigm of education.

Thus, the structural components of textbooks adaptability for elementary schools are considered the following points:

- textbook as strategic and tactical model of the teaching process,

- textbook as a teach-yourself book,

- functionality of the textbook,

- consistency of the textbook with certain education technologies,

- technical side of the textbook.

In accordance with the structural components of technological side of the textbook, we have also proposed the main criteria of studying this quality of the textbook:

- textbook as a strategic and tactical model of the teaching process (aim orientation of the textbook, content orientation, methods and techniques of teaching, forms of organization of educational activities represented in the book),

- textbook as a self-teacher (reflection of the main stages of pedagogical process; motivational, semantic and procedural components of educational activities),

- functionality of the textbook (realization leading functions by means of the textbook - information, developmental, motivational, educational),

- consistency of the textbook with certain education technologies (reflection personality-oriented learning technologies in the textbook - technologies of organization of educational cooperation, technologies of differentiated learning, game educational technology, natureappropriate technologies),

- technicality of the textbook (printing, quality of illustrations, convenience characteristics).

The technology of representation (and hence the method of analysis) in textbooks for junior students, the ability to learn - the key competence of elementary education - has been substantiated. Three-component structure of this competence (content, motivation and procedural components) has been provided, the proposed technology provides the following procedures [27]:

a) presentation in textbooks of information about the culture of mental work, the content of general skills, the ability to learn as an information value (in the form of subject-oriented, instrumentally oriented and valueoriented texts);

b) the availability of tools (learning tasks and exercises) for the formation of skills to organize the workplace, plan learning activities, work with the textbook, analyze, compare, summarize, exercise self- and mutual control;

c) the use of value-oriented texts aimed at making students aware of the importance of knowledge, the formation of lasting interest in learning. 


\section{Conclusions}

Thus, we have systematized the main developments of scientists in the field of school textbook theory in certain areas: its essence, functions, structure, types of textbooks, methods of analysis and evaluation. Emphasis is placed on the peculiarities of the construction of textbooks for elementary school and on the methods of research of certain aspects of the textbook addressed to junior students. As a trend in the development of the theory of school textbooks, we define different of methods for studying certain aspects of a textbook, addressed to junior students

The study does not cover all aspects of the analyzed problem. Further prospects are possible in the analysis of the work of textbooks, relating to the peculiarities of the construction of school textbooks on certain subjects (methodological level of school textbook theory); in the research of didactic bases of interrelation of the textbook with other elements of an educational and methodical complex; in the study of international experience in research, in particular the activities of the Georg Eckert Institute for International Textbook Research (Germany) and the International Association for Research on Textbooks and Educational Media (IARTEM).

\section{References}

[1] V.H. Beilynson, Arsenal Education (Knyha, Moskov, 1986)

[2] V.P. Bespalko, Textbook Theory: Didactic Aspect (Pedagogy, Moscow, 1988)

[3] D.D. Zuev, School textbook (Pedagogy, Moscow, 1983)

[4] E.Y. Perovskyi, News APS RSFSR 63, 3 (1955)

[5] F.M. Gerard, X. Roegiers, Des manuels scolaires pour apprendre: concevoir, évaluer, utiliser (De Boeck Supérieur, 2009)

[6] Y.P. Kodliuk, Theory and practice of textbooks in primary education (Information and analytical agency «Nash chas», Kyiv, 2006)

[7] A. Peyser, F.M. Gerard, X. Roegiers, Planning and changing 37, 37 (2006)

[8] O.M. Topuzov, ed., Examination of school textbooks: instructional and methodical materials for the examination of textbook projects for the 9th grade of comprehensive educational institutions (Pedahohichna dumka, Kyiv, 2016)

[9] N.M. Bibik, Pedahohichna dumka 3, 27 (2003)

[10] L.V. Zankov, School textbook problems 6, 34 (1992)
[11] O.Y. Savchenko, Didactics of primary education (Gramota, 2012)

[12] O.Y. Khrebtova, Ph.D. thesis, Institute of Pedagogics of the NAPS of Ukraine (2011)

[13] N.M. Burynska, Pedagogy and psychology 3, 23 (1999)

[14] V.H. Redko, Designing the content of school textbooks on foreign languages: theory and practice (Pedahohichna dumka, Kyiv, 2017)

[15] I.I. Smahin, Textbook on social studies in the Ukrainian school 1920-1990: problems of creation and functioning (Polissya, Zhytomyr, 2010)

[16] R. Gilbert, Text Analysis and Ideology Critique of Curricular Content (London / New York / Philadelphia, 1989), pp. 61-73

[17] P. Lengrand, An Introduction to Lifelong Education (UNESCO, Paris, 1970)

[18] E. Gachukia, F. Chung, M. Crouch, Textbook Writer's Manual (Economic Commission for Africa, Addis Ababa, 2005), https://unesdoc.unesco. org/ark: /48223/pf0000151037

[19] D. Georgescu, J. Bernard, Thinking and Building Peace through Innovative Textbook Design (UNESCO, Paris, 2007), https://unesdoc. unesco. org/ark: /48223/pf0000161254

[20] J.A. Reints, in New educational media and textbooks, edited by S. Selander, M. Tholey, S. Lorentzen (Stockholm Institute of Education Press, Sweden, 2002), Vol. 2 of IARTEM, p. 141-146

[21] R. Seguin, The Elaboration of school textbooks: methodological Guide (UNESCO, 1989), https://unesdoc.unesco.org/ark: /48223/pf0000086964

[22] Z.Y. Berkyta, Ph.D. thesis, Ternopil Volodymyr Hnatiuk National Pedagogical University (2011)

[23] O.Y. Yanchenko, Ph.D. thesis, Institute of Pedagogics of the NAPS of Ukraine (2006)

[24] I. Lerner, Soviet Education 28, 91 (1986)

[25] I.I. Lerner, N.M. Shakhmaev, eds., What to be a textbook: didactic building principles, Vol. 1 (RAO, Moscow, 1992)

[26] I.I. Lerner, Y.K. Zhuravlev, eds., Modern didacticism: theory - practice (RAO, Moscow, 1993)

[27] Y.P. Kodliuk, Problems of modern textbook 17, 182 (2016)

[28] Y.P. Kodliuk, Problems of modern textbook 12, 432 (2012)

[29] O.Y. Savchenko, Problems of modern textbook 1, 3 (1999) 